\title{
Neuroblastoma stem cells - mechanisms of chemoresistance and histonedeacetylase inhibitors
}

\author{
Minireview $^{* *}$
}

M. A. KHALIL ${ }^{1}$, J. HRABETA ${ }^{1}$, S. CIPRO ${ }^{2}$, M. STIBOROVA ${ }^{3}$, A. VICHA ${ }^{1}$, T. ECKSCHLAGER ${ }^{1, *}$

${ }^{1}$ Department of Pediatric Hematology and Oncology, $2^{\text {nd }}$ Medical Faculty, Charles University and University Hospital Motol, V Uvalu 84,15006 Prague, Czech Republic; ${ }^{2}$ Department of Pathology and Molecular Medicine, $2^{\text {nd }}$ Medical Faculty, Charles University and University Hospital Motol, Prague, Czech Republic; ${ }^{3}$ Department of Biochemistry, Faculty of Science, Charles University, Prague, Czech Republic

*Correspondence: tomas.eckschlager@lfmotol.cuni.cz

Received April 1, 2012 / Accepted July 5, 2012

\begin{abstract}
Cancer stem cells (CSCs) form a small proportion of tumor cells that have stem cell properties: self-renewal capacity, the ability to develop into different lineages and proliferative potential. The interest in CSCs emerged from their expected role in initiation, progression and recurrence of many tumors. They are generally resistant to conventional chemotherapy and radiotherapy. There are two hypotheses about their origin: The first assumes that CSCs may arise from normal stem cells, and the second supposes that differentiated cells acquire the properties of CSCs. Both hypotheses are not mutually exclusive, as it is possible that CSCs have a diverse origin in different tumors. CD133+ cells (CD133 is marker of CSC in some tumors) isolated from NBL, osteosarcoma and Ewing sarcoma cell lines are resistant to cisplatin, carboplatin, etoposide and doxorubicin than the CD133- ones. Being resistant to chemotherapy, there were many attempts to target CSCs epigenetically including the use of histone deacetylase inhibitors. The diverse influence of valproic acid (histone deacetylase inhibitor) on normal and cancer stem cells was proved in different experiments. We have found an increase percentage of CD133+ NBL cells after their incubation with VPA in a dose that does not induce apoptosis. Further researches on CSCs and clinical application for their detection are necessary: (i) to define the CSC function in carcinogenesis, cancer development and their role in metastasis; (ii) to find a specific marker for CSCs in different tumors; (iii) to explain the role of different pathways that determine their behavior and (iv) to explain mechanisms of chemoresistance of CSCs.
\end{abstract}

Key words: Cancer stem cells, CD133, Neuroblastomam, Histone deacetylase inhibitors

Cancer stem cells (CSCs) form a small proportion of tumor cells that have stem cell properties such as self-renewal capacity, the ability to develop into different lineages and proliferative potential $[1,2]$. The interest in CSCs emerged from their expected role in initiation and maintenance of the tumor. Moreover they are supposed to be responsible for resistance to chemotherapy, radiotherapy and early recurrence in many tumors. Its prevalence in solid tumors is higher than that in leukaemia. It shows a variability between different types of tumors and even between tumors of the same type
[3], see Fig. 1. CSCs are characterized by two basic properties: (i) efficiency to initiate cancer and control its proliferation therefore they are sometimes called "tumor initiating cells"; (ii) asymmetrical self-renewing cell division that gives rise to one identical copy of original CSC, and other cancer cell that is more differentiated. Asymmetric division is controlled by extracellular microenvironment, so called "stem cell niche" that supports CSCs growth and regulates their fate [4]. In metastatic process, cells must move out from the original tumor, migrate through blood or lymph, invade into a new

**Presented on the XX. Biological Days - Stem cells - from regenerative medicine to cancer, Pilsen, October 25-27, 2011 


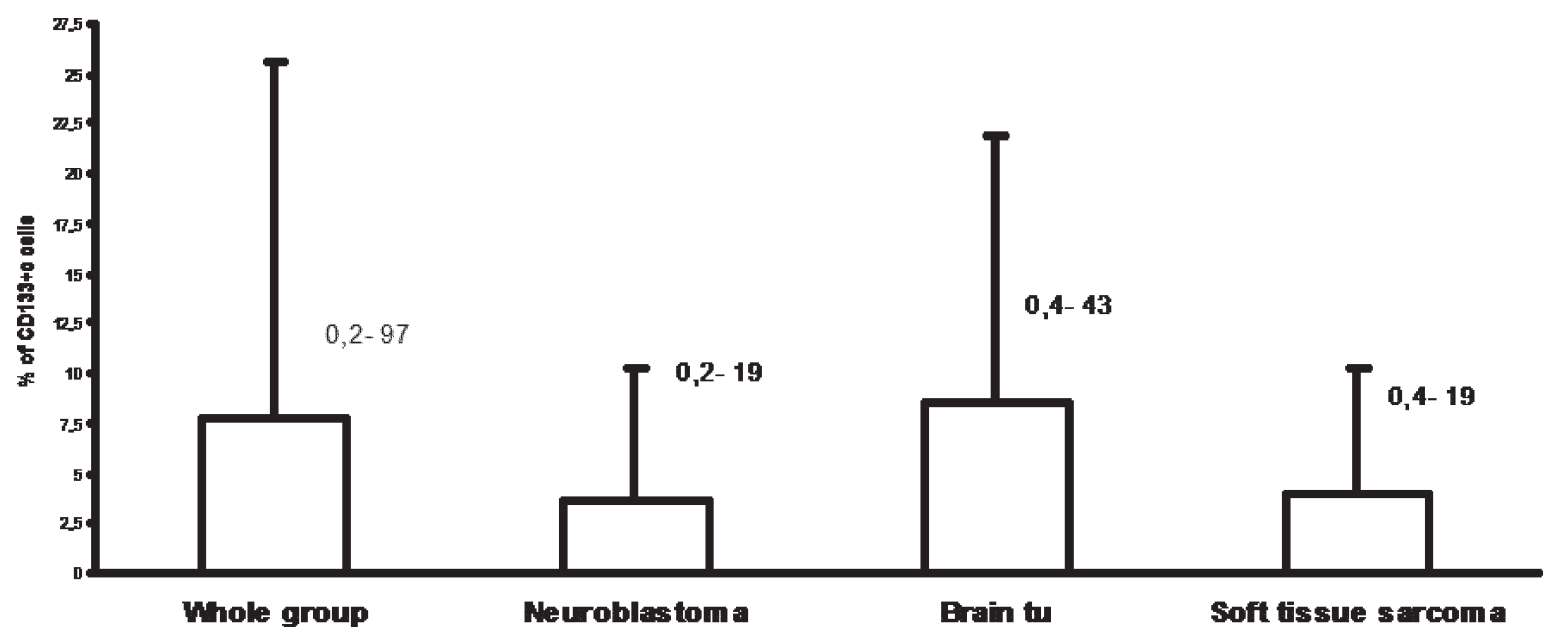

Figure 1. Percentage of CD133+ cells in malignant tumors of childhood. Mean \pm standard deviation, range of values. 40 samples of childhood malignant tumors were examined by flow cytometry. Eckschlager $\mathrm{T}$ et al, unpublished results.

destiny, form micrometastases and develop a new blood supply [5]. Recently, it has been assumed that tumor metastases have their origin directly from CSCs [3]. This assumption is augmented by the finding that VEGF overexpression was detected in CD133+ glioblastoma cells which are located near tumor vessels in experimental tumors, suggesting that CSCs promote local angiogenesis [6].

The origin of CSCs is still a matter of discussion. There are two hypotheses about their origin: The first supposes that CSCs may arise from normal stem cells as they are more susceptible to accumulate oncogenic mutations due to their long life span, and the second supposes that differentiated cells acquire the properties of CSCs [2]. Both hypotheses are not mutually exclusive, as it is possible that CSCs have a diverse origin in different tumors.

Malignant tissue is not homogeneous, because it is composed of various cell populations. This heterogeneity is explained by CSC hypothesis which assumes that tumors are arranged hierarchically and the subpopulation of CSCs is responsible for maintainence of cancer growth [3]. Current chemo- and radiotherapy are based on the traditional tumor model which assumes that malignant cell develops from a mature somatic cell in which multiple genetic changes have occurred and thus acquires self-renewal and multilineage potency. According to the CSC hypothesis a different therapeutical strategy focused mainly on CSCs is required. The CSC hypothesis also enables to explain phenomenon of a minimal residual disease. Even a single CSC that evades the therapies by acquiring resistance recapitulates the whole tumorigenesis resulting in a relapse after complete clinical remission [7].

Originally it was supposed that CSCs are derived from somatic stem cells that had undergone oncogenic mutations which lead to initiate and drive tumor growth [8]. But further experiments have demonstrated that tumors do not always originate from mutated somatic stem cells. For example
Krivtsov et al. induced leukemia in hematopoetic progenitor cells that didn't possess properties of stem cells and grew successfully when transplanted to mice [9].

CSCs can give rise to two daughter cells endowed with stem cell properties, a mode of division that leads to the expansion of the SC pool in a given tissue [10]. In the model of breast cancer, self-renewing divisions of cancer SCs are more frequent than their normal counterparts, unlimited and symmetric, thus contributing to increase the numbers of SCs in tumor tissues. SCs with targeted mutation of the tumor suppressor $\mathrm{p} 53$ possess the same self-renewal properties as cancer SCs, and their number increases progressively in the p53 null premalignant mammary gland [11].

CSCs are more resistant to cytostatics and radiotherapy whether in vivo or in vitro when compared with the majority of the cancer cell population. CSC drug resistance is explained by their slow cycling, efflux of drugs by ABC (ATP Binding Cassette) transporters, and by the upregulation of antiapoptotic genes [12].

CSCs may be influenced by environmental conditions. Glioblastoma cell lines cultivated in normoxic conditions $\left(21 \% \mathrm{O}_{2}\right)$ have very low expression of CD133+ cells (marker of CSC in brain and some other tumors see below). The expression of CD133 increases in hypoxia $\left(1 \% \mathrm{O}_{2}\right)$ and maintained high as long as they are cultivated in hypoxic conditions while its percentage progressively decreased on exposure to normoxic condition again. CD133+ cells percentage was also found to increase by the decrease in mitochondrial membrane potential $\left(\Delta \Psi_{\mathrm{m}}\right)$ that is induced by rotenone [13]. The increase of CD133+ cells in hypoxia is probably due to increase in the expression of HIF-1a protein as its knockdown inhibits the hypoxia-mediated expansion of CD133+ tumor cells [14]. One may speculate that the increase in CSCs in hypoxia may participate in hypoxia-induced chemo- and radioresistance. Colon cancer cell lines infected by Mycoplasma hyorhinis, one 


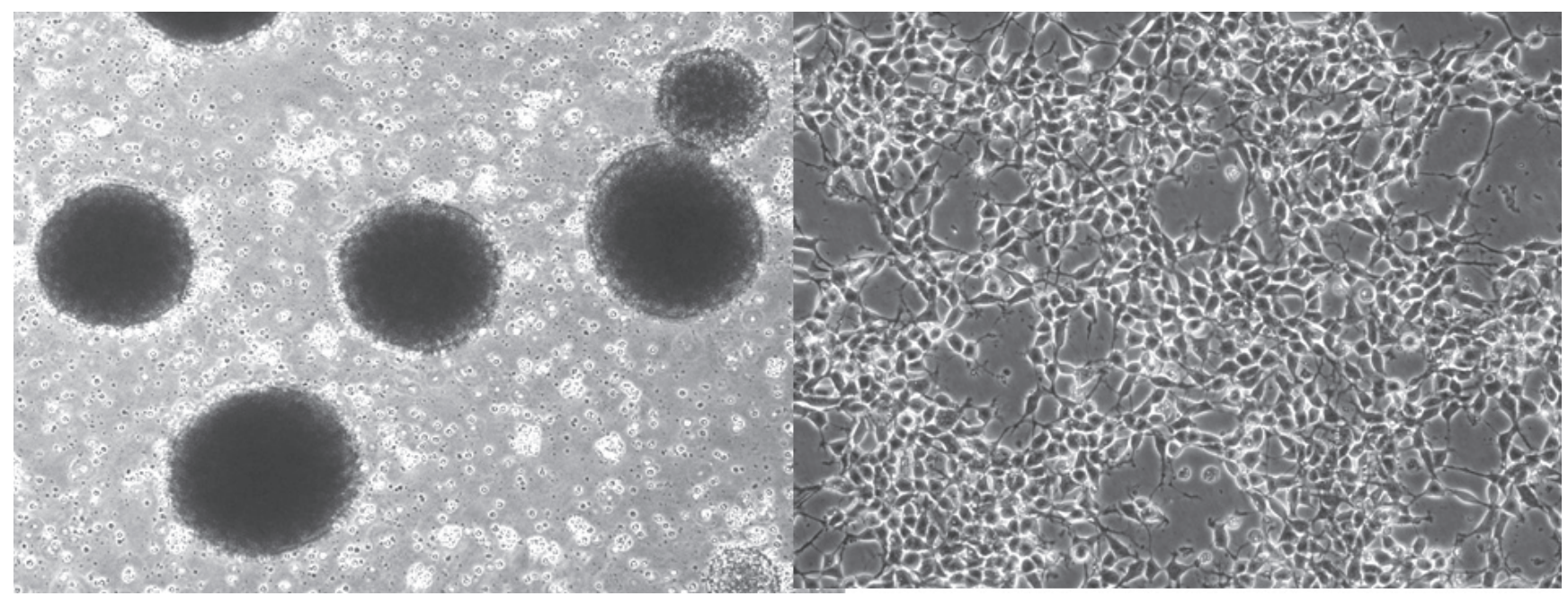

Figure 2. Neuroblastoma cell line UKF-NB-3. Cultivated in serum-free medium consisting of: DMEM/F12 medium supplemented with bFGF, EGF, B-Mercaptoethanol, Heparin N2 and B27 supplements- left, Iscove's modified Dulbecco's medium (IMDM) with 10\% serum- right. Neurospheres in serum free medium and attached growth in IMDM with serum. Olympus IX51, magnification 100x.

of the most common cell culture contaminants, had a higher percentage of CD133+ cells than the same mycoplasma-free lines. This phenomenon may be explained by resistance of CSCs to toxicity of mycoplasma or artificially by the influence of antibody binding [15].

CSC detection. CSCs may be defined by their tumorigenicity in vivo, but in practice they are usually detected by the presence or combination of various antigens such as CD24, CD44, CD133, aldehyde dehydrogenase (ALDH) activity and Hoechst efflux (so-called side population) in various malignant tumors. Side population has been defined by using the fluorescent dyes rhodamine 123 and Hoechst 33342 as cells that can rapidly efflux the Hoechst dye to produce a characteristic profile based on flow cytometric analysis. The side population phenotype is associated with high-level expression of the ATPbinding cassette transporter protein ABCG2 /Bcrp1 [16]. The ATP-binding cassette (ABC) transporter superfamily contains membrane proteins that translocate a wide variety of substrates across extra- and intracellular membranes, including drugs. Overexpression of certain $\mathrm{ABC}$ transporters occurs in cancer cells that are multidrug resistant.

Cells expressing the above mentioned antigens can be isolated by fluorescence activated cell sorting (FACS) or by immunomagnetic separation [17]. Isolated CSCs have shown to be highly clonogenic, tumorigenic in vivo, and they can grow as spheres in serum-free media. Neurosphere assays are based on the cultivation of cancer cells from neuronal origin in selective serum-free media with growth factors (EGF, bFGF) and supplemented with B27, in which stem-like cells are able to divide continuously and form multipotent clonal spheres so-called neurospheres, while the more differentiated cells die under such conditions [18] (Fig. 2). It has been observed that isolated CD133+ cells grow as neurospheres and the CD133+ cell percentage correlates with the neurosphere-forming ability in glioblastomas cell lines. However, in single cell cultivation, the majority of CD133+ tumor cells were not able to form spheres. Similar correlation was noticed between neurospheres with side population and side population with CD133+ cells percentage. None of the three methods mentioned above is ideal for detection of CSCs. The population of cells defined by each of these methods represents heterogeneous populations which overlap each other [19]. The potential difficulties associated with each method complicate the interpretation of results. Therefore more sensitive and specific methods for detection of CSCs need to be developed.

There are several reports about the role of microRNA (miRNA) in regulation of CSCs. It represents a cluster of small non-coding RNA molecules consisting of 21-23 nucleotides that control the expression of specific genes at the post-transcriptional level. Their detection in cancer tissues or in serum may be used for improvement of diagnosis, prognosis determination or prediction of therapeutic efficiency. There is a hope that it will be possible to develop targeted therapy of miRNA directed against CSCs [20]. For example, it was found in neuroblastoma cell line SH-SY5Y that expression of miRNA-214 increased, whereas expression of miRNA-7 decreased during retinoic acid induced differentiation [21].

CD133. Yin et al. found that CD133 is expressed in part of CD34 + human hematopoetic stem cells [22]. It has been reported that $\mathrm{CD} 133+/ \mathrm{CD} 34+$ cells had higher clonogenicity and an engraftment rate after experimental transplantation compared to CD133-/CD34+ cells [23]. Therefore, CD133 became another marker used for identification and separation of stem and precursor cells. Later, the CD133 + cells have been studied in different tissues, other than the hematological system, e.g. endothelial precursors cells, fetal brain stem cells, embryonic 
epithelial cells, prostate epithelial stem cells, progenitor cells with myogenic potential [24-28]. When CSCs were defined by their properties (self-renewal capacity, infinity of proliferation, differentiation potential and high oncogenicity), many groups found different CSC markers such as CD133, nestin, CD326 [29].

Initially, the CD133 cells were reported as a marker of CSCs in medulloblastoma and glioblastoma. Singh et al. screened out CD133 + cells from brain tumor using anti CD133 antibody and found that these cells had very strong capabilities of proliferation, selfrenewal and differentiation [30]. Later, CD133 antigen was detected in CSCs of melanoma, pancreatic, colorectal, liver, prostate, renal, head and neck spinocelular, ovarian, and both small and non-small cell lung carcinomas [31-39]. Whereas the molecular structure of CD133 has already been characterized, the function of this molecule is still unknown. CD133 gene is located on chromosome 4p15.3-p15.2. Seven splice variants affecting the open reading frame in humans have been identi- fied. Factors that regulate CD133 expression are not known, but the mRNA profile suggests that the splice variants are tissue specific and developmentally regulated [40]. The CD133 protein could be detected on a cell surface, and it is frequently intracellular with accumulations located in the endoplasmic reticulum and/or Golgi apparatus, but seemingly unrelated to particular CD133 splice variants or protein epitopes. In contrast, membrane-bound expression of CD133 was restricted to tumor cells bearing the extracellular CD133 epitope AC133 [41]. The CD133+ cells from different human tumors were more tumorigenic in immuno-deficient mice rather than the CD133- ones [42]. CD133+ cells from different cancers are chemoresistant and have been enriched in vivo after treatment with cisplatin, etoposide, doxorubicin, and paclitaxel [19, 43].

CD133+ cells from ovarian cancer and neuroblastoma had a greater S-phase fraction than CD133- cells $[44,45]$ see Fig. 3 This is in concordance with the report of Jaksch, who
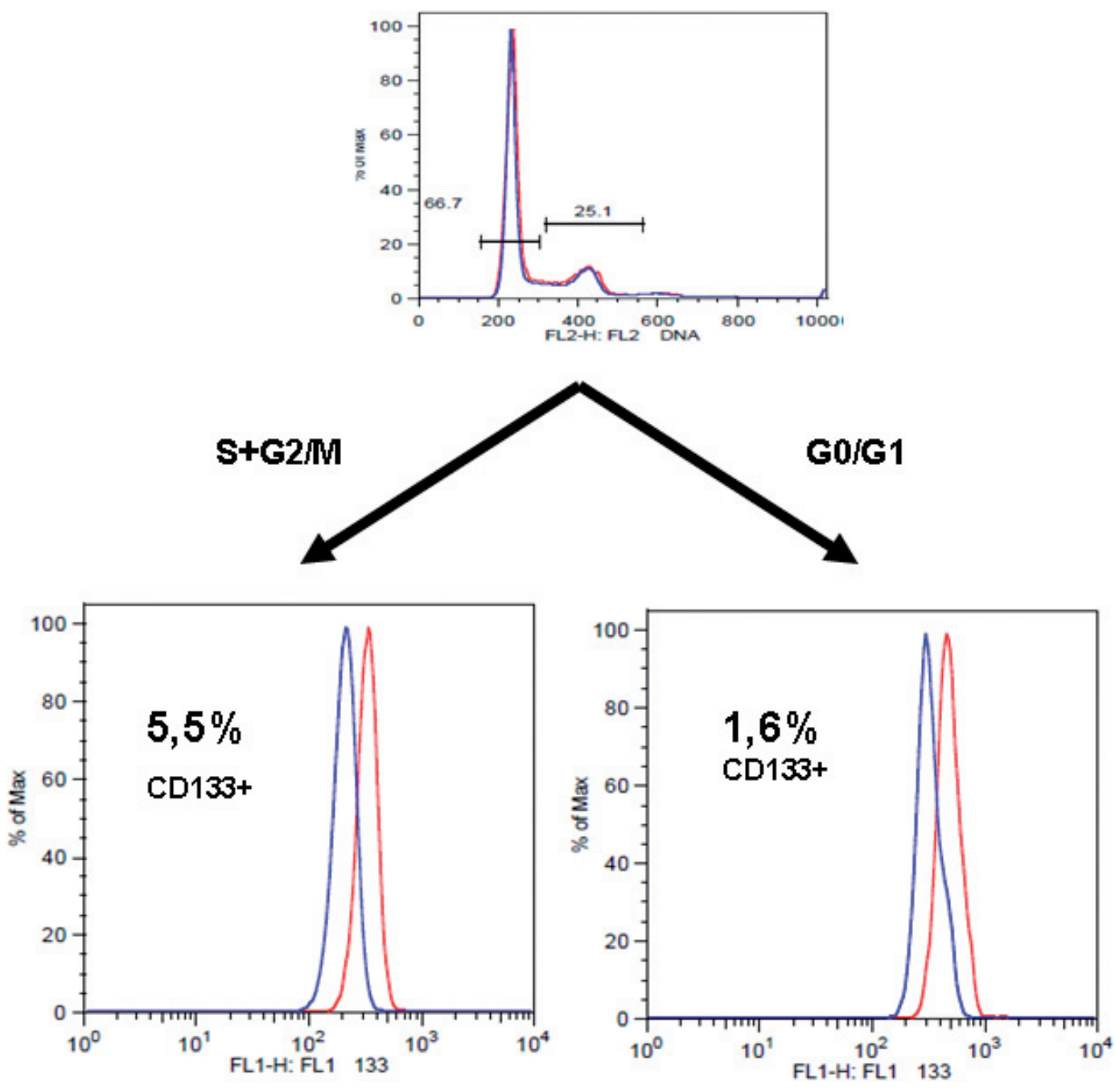

Figure 3. CD133+ cells in proliferative fraction (S+G2/M phase) and in G0/G1 phase. There was increased percentage of CD133+ cells in proliferative fraction compared with G0/G1 phase. Blue curve - isotypic control; red curve- anti-CD133 antibody. 
showed that the colon cancer, melanoma, and human embryonic stem cells with 4N DNA content had higher CD133 expression than the cells with 2N DNA [46]. Hence CD133 can be a proliferation marker, as well as a marker of tumor initiating cells.

CSCs in Neuroblastoma (NBL). NBL is the most common extracranial solid tumor in children and a major cause of neoplastic death in infancy. It originates from undifferentiated cells of the sympathetic nervous system. Based on its cellular and biological heterogeneity, NBL behavior can range from low-risk (LR) cancers with a tendency toward spontaneous regression or maturation, to high-risk (HR) ones with extensive growth, early metastasis and a poor prognosis [47]. Stage, age, histologic category, grade of tumor differentiation, the status of the MYCN oncogene, chromosome 11q status, and DNA ploidy have been proposed as a stratifying prognostic markers in the International Neuroblastoma Risk Group classification system [48]. During the past 20 years, much effort has been directed towards the improvement of treatment results in HR NBL, but until know die more than $60 \%$ of children suffering from HR NBL. Intensive chemotherapy, including the introduction of high-dose chemotherapy with autologous stem cell transplantation and more recently maintenance therapy including differentiation agents and immunotherapy have contributed to further improvement. To improve the prognosis of children with HR NBL research has focused on the following areas: (1) improvement of earlier diagnosis of the disease; (2) studies to detect minimal residual disease; (3) attempts to influence the biology of the disease; (4) definition of new risk factors; (5) development of new therapeutic strategies; and (6) research of targeted therapy, such as $\mathrm{I}^{131}$-MIBG systemic radiotherapy, monoclonal antibodies, antiangiogenic therapy, insulin-like growth factor-1 receptor inhibitors, aurora kinase A inhibitor, several ALK inhibitors and multikinase inhibitor sunitinib $[49,50]$. Frequent treatment failure in HR NBL is due to drug resistance that occurs in the majority of patients who initially responded well to chemotherapy. The necessity to develop new treatment modalities for HR NBL is indisputable.

Cellular heterogeneity is a feature of human NBL tumors and cell lines and it correlates with clinical behavior. These properties have been used for the classification and prognosis of the disease. The same cellular heterogeneity is manifested in cell lines derived from these tumors. Three distinct cellular phenotypic variants in human neuroblastoma cell lines have been identified: (i) neuroblastic ( $\mathbf{N}$ type), the most common type, grows as poorly attached aggregates of small rounded cells with short neuritic processes; (ii) Schwann (S type) resembles non-neuronal precursor cells, as these large flattened cells attach strongly to the substrate and show contact inhibition in their growth pattern; (iii) I type represents a more primitive cell type, a progenitor of $\mathrm{N}$ - or S-type. I type shows intermediate characters and morphology in between $\mathrm{N}$ and $S$ types. They are small, flattened, moderately adherent cells, with or without neuritic processes. Cells of this type form aggregates when grow in the culture [51].
Studies investigating malignant potential of human NBL cell lines showed that I-type cell lines are the most tumorigenic ones. Stem cells derived from I type have more ability to differentiate into different cell types than other types, having a high colony-forming capacity and high growth potential in immunodeficient mice. It has been proved that malignant stem cell phenotype (CD133 and c-kit expression), but not MYCN amplification status or its expression, defines the tumorigenic potential of the various NBL cell lines [52]. Those results were also proved by examination of 40 tumor samples which showed that percentage of CD133 + cells was higher in neuroblastoma than in ganglioneuroblastoma, correlated with clinical stage, and was higher in tumors with unfavorable than favorable histology. In addition, the median survival time of patients with CD133- tumors was longer than those with CD133+ ones [53]. The question arises, whether the presence of CD133+ cells is an independent prognostic marker or it only correlates with other prognostic markers such as histology or the clinical stage. Knockdown of CD133 inhibits differentiation of NBL cell lines and primary tumor cells, which is dependent on RET tyrosine kinase expression. Inhibition of CD133 using siRNA increases RET expression in NBL cells. RET repression and NBL differentiation are caused by activation of p38MAPk or PI3K/Akt pathways [54]. CD133 knockdown inhibits sphere formation in NBL cell line suggesting that CD133 appears to have a role in tumor cell stemness in NBL [55].

Only NBL stage 4-derived cells generate spheres, however the MYCN expression status was not related to the sphere forming ability. The sphere-forming cells, selected from the highly malignant NBL tumor samples are resistant to doxorubicin, cisplatin and etoposide compared to cells cultivated in medium with serum. Average CD133 expression was also increased in spheres but not in every analyzed sphere derived from NBL samples and cell lines [56]. This finding doubts the significance of CD133 as an universal marker of all CSCs in NBL and shows that is unreliable to detect CSCs using a single marker.

Hansford et al. (2007) studied tumor-initiating capacity of cells from bone marrow metastasis of NBL. They found that NBL cells, both HR and LR isolated from bone marrow metastases and grew as spheres in a serum-free medium, were self-renewing and have chromosomal aberrations typical for NBL [57]. Cells from spheres that were derived from HR NBL had higher self-renewal capacity than those from low-risk NBL. Even only 10 cells isolated from HR NBL derived spheres were able to induce tumors that metastasize in an orthotopic mouse model. Those data indicate that NBL contains CSCs and that those cells have metastasizing potential [57]. The differences between possibility of LR NBL cells to form spheres which were described by Coulon and Hansford might be explained by source of the cells. Hansfrod et al examined cells isolated from bone marrow metastases and those cells form spheres regardless of the risk group. While Coulon et al. used isolated cells from primary tumors that had grown as spheres only when they were derived from HR NBL [56]. 
NBL CSCs have a different genetic profile than „non-stem tumor cells" in NBL cell lines and in tumors. Cournoyer et al found using the Affymetrix Genome-Wide Human SNP Array 6.0 that CD133+ cells isolated from six NBL cell lines have gains on $16 \mathrm{p} 13.3,19 \mathrm{p} 13.3$, and $19 \mathrm{q} 13.33$ that are absent in CD133- cells. There was correlation between the presence of a gain of $16 \mathrm{p} 13$ and the expression of CD133 in 26 samples of NBL [58].

Other property of NBL CSC that seems to be clinically significant is telomerase activity. Telomere - repetitive sequences of DNA at the ends of chromosomes protect them from degradation. Because of the end-replication problem, telomeres become shorter, with each cellular division resulting in cellular senescence. Immortal cells e.g. germ cells, stem cells, and memory lymphocytes are thought to maintain telomeres for self-renewal through reactivation of the telomerase. This is a complex ribonucleoprotein composed in part of telomerase RNA (TR) and the telomerase reverse transcriptase. 90\% - 95\% of human cancers maintain their telomeres through telomerase activation. Spontaneous regression of low risk NBL was found in tumors that lack telomerase activity. Castelo-Branco et al found that telomerase activity is not a property of all glioblastoma and NBL tumor cells but rather confined only to the CSC subpopulation and is not detectable in the majority of cancer cells. Furthermore, normal tissue stem cells lack telomerase activity and therefore are insensitive to telomerase inhibition, which is a highly specific and effective anti-CSC therapy. Furthermore, as opposed to conventional chemotherapies, telomerase inhibition resulted in CSC exhaustion by irreversibly altering their self-renewal kapacity [59].

Smith KM et al. identified compounds that selectively targeted NBL cells with CSC properties while having little effect on normal stem cells. They found two compounds - dequalinium analogue (DECA-14) and rapamycin, that prevent NBL CSC self-renewal both in vitro and in vivo. This difference suggest that CSC in NBL play important role in metastases development [60].

Chemoresistance of NBL CSCs. CD133+ cells from different cancers are chemoresistant and have been enriched in vivo after treatment with cisplatin, etoposide, doxorubicin, and paclitaxel $[19,43]$.

The NBL derived side population was capable of sustained expansion in vitro and demonstrated asymmetric division. The side population cells expressed high levels of $A B C G 2$ and $A B C A 3$ transporter genes and had capacity to expel mitoxantrone, resulting in better survival of side population cells during cultivation with this cytostatics [61]. ABCG2 (known also as breast cancer resistance protein - BCRP) trasnport not only mitoxantrone but also anthracycline cytostatics, imatinib and topoisomerase I and II inhibitors.

The CD133+ cells isolated from NBL, osteosarcoma and Ewing sarcoma cell lines showed to be more resistant to cisplatin, carboplatin, etoposide and doxorubicin than the CD133- ones. Furthermore, a decrease in apoptosis was observed in $\mathrm{CD} 133+$ cells after incubation with above mentioned cytostatics. CD133+ NBL SK-NSH cells expressed less MKP-1 and more phosphorylated forms of both ERK and P-38 kinases [62]. Mitogen-activated protein kinases (MAP kinases) influence cell-cycle progression, differentiation and cell death. The differential expression of some MAP kinases such as P-38, JNK, ERK, and P13K significantly influences cell death. Omichi et al described that DNA damage caused by cisplatin activated JNK and ERK cascades in different ways, and their inhibition sensitized cancer cells to cisplatin [63]. MKP-1 dephosphorylates ERK, JNK, and P-38 in the cell nucleus [64]. Therefore higher expression of MKP-1 in CD133- cells is related to increase dephosphorylation of P-38 and ERK seen in those cells. This phenomenon might explain one of the mechanisms of chemoresistance in CSCs of NBL [62]. The significance of CSCs in tumor recurrence caused presumably by chemoresistance was confirmed by Newton et al. These authors found that the size of the side population in cell lines established from recurrent tumors was increased compared to its paired pretreatment cell line [65]. In addition, the side population cells from recurrent NBLs showed an increased proliferation, and were more coloniforming [65].

Epigenetical influencing of CSCs. Being resistant to chemotherapy, there were many attempts to target CSCs epigenetically. Valproic acid (VPA) has been used for treatment of epilepsy since the 1970s and it was demonstrated that it also inhibits histone deacetylases (HDAC). Recently, this drug has been tested in differentiation therapy of AML and MDS [66]. In contrast to the experiments, which show that VPA caused differentiation in AML, it found to increase the percentage of normal haematopoietic stem cells (HSC) more than in differentiated cells. In in-vivo experiments VPA increased the capability of HSC to repopulate bone marrow of lethal irradiated mice [67]. VPA exhibits different effects on normal haematopoietic stem cells than on the leukemic blasts. There is a relationship between differentiation and the response to VPA. Immature cells respond with a down-regulation of p21cip-1/waf-1 that cause progression of cell cycle, while more differentiated cells respond with its down-regulation that will induce differentiation or apoptosis. The explanation for these phenomena is that VPA increases self-renewal of HSC probably by the inhibition of GSK3h through its phosphorylation that activates Wnt signaling pathway. Wnt signaling is important for the self-renewal property of stem cells [67]. Both experimental and clinical studies showed that VPA potentiates the effect of various cytostatics that is explained by the enhancement of apoptosis, the up-regulation of p21cip-1/waf- 1 expression and/or the impact of HDAC inhibitors on chromatin structure. HDAC inhibitors facilitate decondensation of chromatin by increasing the acetylation of several histones, hence relaxed chromatin is more sensitive to ionizing radiation and DNAdamaging agents. They also reduce double strand break repair capacity [66]. The data that show the diverse influence of VPA on normal and cancer stem cells seem to be very important for clinical practice. VPA in nontoxic concentrations sensitized the adherent or differentiated breast cancer cells (primocultures 

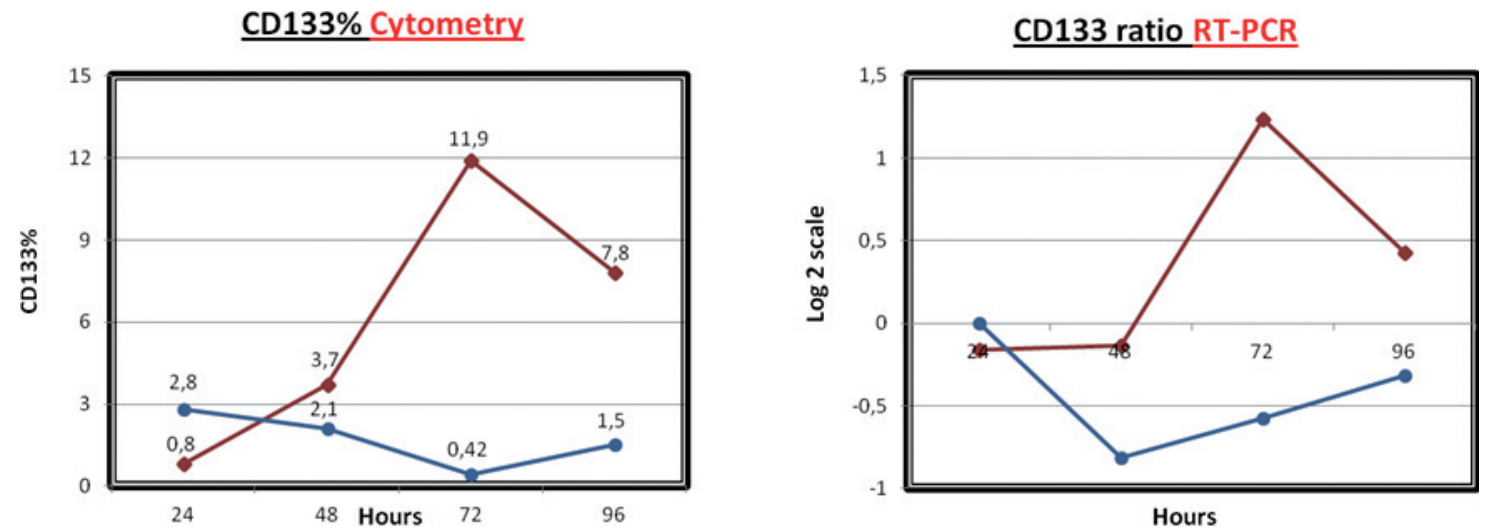

Figure 4. Changes of CD133 expression after incubation of NBL cell line UKF-NB3 with 1mM VPA. CD133 was detected by flow cytometry (surface expression) - left figure, or by real time RT PCR- right figure. Red curve - incubation with VPA; blue curve - controls without VPA. Typical results of one of the four experiemts.

and cell lines) to ionizing radiation that were monitored using clonogenic assay but not CSCs as evaluated by sphere formation assay. Unlike the effect on more differentiated cancer cells, VPA had a radioprotective effect on CSCs. These facts were approved by results found in in-vitro experiments showing that VPA may increase CSCs after radiotherapy [68].

Decitabine (a methyltransferase inhibitor) or trichostatin A (an HDAC inhibitor) induced an increase in surface expression of CD133 in the selected CD133- ovarian cancer cells. Combination of both drugs had synergistic effect on CD133 expression. The explanation of this phenomenon may be that DNA methylation silences CD133 expression and that histone deacetylation influences regulation of the CD133 promotor [69]. Recently, we have found an increase in percentage of CD133+ NBL cells after their incubation with VPA in a dose that did not induce apoptosis [45] (see Fig 4). We showed that VPA induced death in NBL cells growing both under normoxic and hypoxic conditions and can overcome hypoxia induced resistance to cisplatin-induced apoptosis in HR NBL cells [70]. However, the question remains whether those changes are connected with hypoxic induction of CSCs, or whether VPA affects only more differentiated cells.

Until now, our knowledge is still limited to consider HDAC inhibitors as CSCs targeted therapy.

Future directions. CSCs are one of the most intensively studied topics in current oncology. More than 35, 000 articles are found in PubMed, when using the key words "cancer stem cell ${ }^{\star}$. However we are missing the basic information which is necessary for further research on CSCs and clinical application for their detection in diagnostics and CSC target therapy. It is necessary to: (i) define the CSC function in cancerogenesis, cancer development and their role in metastasis and chemoresistance; (ii) find a specific marker for CSCs in certain tumors; (iii) explain the role of different pathways that determine their behavior and (iv) resolve mechanisms of chemoresistance of CSCs $[2,7,8,17,56]$.
Acknowledgments: This study was supported by grant GACR P301/10/0356 and by the project for conceptual development of research organization 00064203 .

\section{References}

[1] REYA T, MORRISON SJ, CLARKE MF, WEISSMAN IL. Stem cells, cancer, and cancer stem cells. Nature 2001; 414, 105-111. http://dx.doi.org/10.1038/35102167

[2] BOHL SR, PIRCHER A, HILBE W. Cancer stem cells: characteristics and their potential role for new therapeutic strategies. Onkologie 2011; 34, 269-274. http://dx.doi. org/10.1159/000327815

[3] VISVADER JE, LINDEMAN GJ. Cancer stem cells in solid tumours: accumulating evidence and unresolved questions. Nat Rev Cancer 2008; 8, 755-768. http://dx.doi.org/10.1038/ $\underline{\operatorname{nrc} 2499}$

[4] LI L, BHATIA R. Stem cell quiescence. Clin Cancer Res 2011; 17, 4936-4941. http://dx.doi.org/10.1158/1078-0432.CCR-10$\underline{1499}$

[5] CROKER AK, ALLAN AL. Cancer stem cells: implications for the progression and treatment of metastatic disease. J Cell Mol Med 2008; 12, 374-390. http://dx.doi.org/10.1111/j.15824934.2007.00211.x

[6] FOLKINS C, SHAKED Y, MAN S, TANG T, LEE CR et al. Glioma tumor stem-like cells promote tumor angiogenesis and vasculogenesis via vascular endothelial growth factor and stromal-derived factor 1. Cancer Res 2009; 69, 7243-7251. http://dx.doi.org/10.1158/0008-5472.CAN-09-0167

[7] WELTE Y, ADJAYE J, LEHRACH HR, REGENBRECHT CR. Cancer stem cells in solid tumors: elusive or illusive? Cell Commun Signal 2010; 8, 6. http://dx.doi.org/10.1186/1478$\underline{811 X-8-6}$

[8] RAHMAN M, DELEYROLLE L, VEDAM-MAI V, AZARI H, ABD-EL-BARR $M$ et al. The cancer stem cell hypothesis: failures and pitfalls. Neurosurgery $2011 ; 68,531-545$; discussion 545. http://dx.doi.org/10.1227/NEU.0b013e3181ff9eb5 
[9] KRIVTSOV AV, TWOMEY D, FENG Z, STUBBS MC, WANG $Y$ et al. Transformation from committed progenitor to leukaemia stem cell initiated by MLL-AF9. Nature 2006; 442, 818-822. http://dx.doi.org/10.1038/nature04980

[10] MORRISON SJ, KIMBLE J. Asymmetric and symmetric stemcell divisions in development and cancer. Nature 2006; 441, 1068-1074. http://dx.doi.org/10.1038/nature04956

[11] CICALESE A, BONIZZI G, PASI CE, FARETTA M, RONZONI S et al. The tumor suppressor $\mathrm{p} 53$ regulates polarity of self-renewing divisions in mammary stem cells. Cell 2009; 138, 1083-1095. http://dx.doi.org/10.1016/j.cell.2009.06.048

[12] EYLER CE, RICH JN. Survival of the fittest: cancer stem cells in therapeutic resistance and angiogenesis. J Clin Oncol 2008; 26, 2839-2845. http://dx.doi.org/10.1200/JCO.2007.15.1829

[13] GRIGUER CE, OLIVA CR, GOBIN E, MARCORELLES P, BENOS DJ et al. CD133 is a marker of bioenergetic stress in human glioma. PLoS One 2008; 3, e3655. http://dx.doi. org/10.1371/journal.pone.0003655

[14] SOEDA A, PARK M, LEE D, MINTZ A, ANDROUTSELLISTHEOTOKIS A et al. Hypoxia promotes expansion of the CD133-positive glioma stem cells through activation of HIF-1alpha. Oncogene 2009; 28, 3949-3959. http://dx.doi. org/10.1038/onc.2009.252

[15] MARIOTTI E, GEMEI M, MIRABELLI P, DAALESSIO F, DI NOTO R et al. The percentage of CD133+ cells in human colorectal cancer cell lines is influenced by Mycoplasma hyorhinis infection. BMC Cancer 2010; 10, 120. http://dx.doi. org/10.1186/1471-2407-10-120

[16] HIRSCHMANN-JAX C, FOSTER AE, WULF GG, NUCHTERN JG, JAX TW et al. A distinct „side population“ of cells with high drug efflux capacity in human tumor cells. Proc Natl Acad Sci U S A 2004; 101, 14228-14233. http://dx.doi. org/10.1073/pnas.0400067101

[17] CLARKE MF, DICK JE, DIRKS PB, EAVES CJ, JAMIESON $\mathrm{CH}$ et al. Cancer stem cells--perspectives on current status and future directions: AACR Workshop on cancer stem cells. Cancer Res 2006; 66, 9339-9344.

[18] HEMMATI HD, NAKANO I, LAZAREFF JA, MASTERMAN-SMITH M, GESCHWIND DH et al. Cancerous stem cells can arise from pediatric brain tumors. Proc Natl Acad Sci U S A 2003; 100, 15178-15183. http://dx.doi.org/10.1073/ pnas. 2036535100

[19] WAN F, ZHANG S, XIE R, GAO B, CAMPOS B et al. The utility and limitations of neurosphere assay, CD133 immunophenotyping and side population assay in glioma stem cell research. Brain Pathol 2010; 20, 877-889.

[20] ZHAO L, CHEN X, CAO Y. New role of microRNA: carcinogenesis and clinical application in cancer. Acta Biochim Biophys Sin (Shanghai) 2011; 43, 831-839. http://dx.doi. org/10.1093/abbs/gmr080

[21] CHEN H, SHALOM-FEUERSTEIN R, RILEY J, ZHANG SD, TUCCI $P$ et al. miR-7 and miR-214 are specifically expressed during neuroblastoma differentiation, cortical development and embryonic stem cells differentiation, and control neurite outgrowth in vitro. Biochem Biophys Res Commun 2010; 394, 921-927. http://dx.doi.org/10.1016/ j.bbrc.2010.03.076
[22] YIN AH, MIRAGLIA S, ZANJANI ED, ALMEIDA-PORADA G, OGAWA $M$ et al. AC133, a novel marker for human hematopoietic stem and progenitor cells. Blood 1997; 90, 5002-5012.

[23] DE WYNTER EA, BUCK D, HART C, HEYWOOD R, COUTINHO LH et al. CD34+AC133+ cells isolated from cord blood are highly enriched in long-term culture-initiating cells, NOD/SCID-repopulating cells and dendritic cell progenitors. Stem Cells 1998; 16, 387-396. http://dx.doi. org/10.1002/stem.160387

[24] PEICHEV M, NAIYER AJ, PEREIRA D, ZHU Z, LANE WJ et al. Expression of VEGFR-2 and AC133 by circulating human CD34(+) cells identifies a population of functional endothelial precursors. Blood 2000; 95, 952-958.

[25] UCHIDA N, BUCK DW, HE D, REITSMA MJ, MASEK M et al. Direct isolation of human central nervous system stem cells. Proc Natl Acad Sci U S A 2000; 97, 14720-14725. http://dx.doi. org/10.1073/pnas.97.26.14720

[26] CORBEIL D, ROPER K, HELLWIG A, TAVIAN M, MIRAGLIA $S$ et al. The human AC133 hematopoietic stem cell antigen is also expressed in epithelial cells and targeted to plasma membrane protrusions. J Biol Chem 2000; 275, 55125520. http://dx.doi.org/10.1074/jbc.275.8.5512

[27] RICHARDSON GD, ROBSON CN, LANG SH, NEAL DE, MAITLAND NJ et al. CD133, a novel marker for human prostatic epithelial stem cells. J Cell Sci 2004; 117, 3539-3545. http://dx.doi.org/10.1242/jcs.01222

[28] TORRENTE Y, BELICCHI M, SAMPAOLESI M, PISATI F, MEREGALLI $M$ et al. Human circulating AC133(+) stem cells restore dystrophin expression and ameliorate function in dystrophic skeletal muscle. J Clin Invest 2004; 114, 182-195.

[29] ZHANG H, LI SY. Research progression of CD133 as a marker of cancer stem cells. Chin J Cancer 2010; 29, 243-247. http:// dx.doi.org/10.5732/cjc.009.10587

[30] SINGH SK, HAWKINS C, CLARKE ID, SQUIRE JA, BAYANI $\mathrm{J}$ et al. Identification of human brain tumour initiating cells. Nature 2004; 432, 396-401. http://dx.doi.org/10.1038/ $\underline{\text { nature } 03128}$

[31] OLEMPSKA M, EISENACH PA, AMMERPOHL O, UNGEFROREN H, FANDRICH F et al. Detection of tumor stem cell markers in pancreatic carcinoma cell lines. Hepatobiliary Pancreat Dis Int 2007; 6, 92-97.

[32] O'BRIEN CA, POLLETT A, GALLINGER S, DICK JE. A human colon cancer cell capable of initiating tumour growth in immunodeficient mice. Nature 2007; 445, 106-110. http:// dx.doi.org/10.1038/nature05372

[33] SUETSUGU A, NAGAKI M, AOKI H, MOTOHASHI T, KUNISADA T et al. Characterization of CD133+ hepatocellular carcinoma cells as cancer stem/progenitor cells. Biochem Biophys Res Commun 2006; 351, 820-824. http://dx.doi. org/10.1016/j.bbrc.2006.10.128

[34] COLLINS AT, BERRY PA, HYDE C, STOWER MJ, MAITLAND NJ. Prospective identification of tumorigenic prostate cancer stem cells. Cancer Res 2005; 65, 10946-10951. http:// dx.doi.org/10.1158/0008-5472.CAN-05-2018

[35] BRUNO S, BUSSOLATI B, GRANGE C, COLLINO F, GRAZIANO ME et al. CD133+ renal progenitor cells contrib- 
ute to tumor angiogenesis. Am J Pathol 2006; 169, 2223-2235. http://dx.doi.org/10.2353/ajpath.2006.060498

[36] ZHOU L, WEI X, CHENG L, TIAN J, JIANG JJ. CD133, one of the markers of cancer stem cells in Hep-2 cell line. Laryngoscope 2007; 117, 455-460. http://dx.doi.org/10.1097/01. mlg.0000251586.15299.35

[37] MONZANI E, FACCHETTI F, GALMOZZI E, CORSINI E, BENETTI A et al. Melanoma contains CD133 and ABCG2 positive cells with enhanced tumourigenic potential. Eur J Cancer 2007; 43, 935-946. http://dx.doi.org/10.1016/ j.ejca.2007.01.017

[38] ERAMO A, LOTTI F, SETTE G, PILOZZI E, BIFFONI M et al. Identification and expansion of the tumorigenic lung cancer stem cell population. Cell Death Differ 2008; 15, 504-514. http://dx.doi.org/10.1038/sj.cdd.4402283

[39] FERRANDINA G, BONANNO G, PIERELLI L, PERILLO A, PROCOLI A et al. Expression of CD133-1 and CD133-2 in ovarian cancer. Int J Gynecol Cancer 2008; 18, 506-514. http://dx.doi.org/10.1111/j.1525-1438.2007.01056.x

[40] FARGEAS CA, HUTTNER WB, CORBEIL D. Nomenclature of prominin-1 (CD133) splice variants - an update. Tissue Antigens 2007; 69, 602-606. http://dx.doi.org/10.1111/j.13990039.2007.00825.x

[41] CAMPOS B, ZENG L, DAOTRONG PH, ECKSTEIN V, UNTERBERG A, MAIRBAURL H, HEROLD-MENDE C. Expression and regulation of AC133 and CD133 in glioblastoma. Glia 2011; 59, 1974-1986. http://dx.doi. org/10.1002/glia.21239

[42] KEYSAR SB, JIMENO A. More than markers: biological significance of cancer stem cell-defining molecules. Mol Cancer Ther 2010; 9, 2450-2457. http://dx.doi.org/10.1158/15357163.MCT-10-0530

[43] CHEN YC, HSU HS, CHEN YW, TSAI TH, HOW CK et al. Oct-4 expression maintained cancer stem-like properties in lung cancer-derived CD133-positive cells. PLoS One 2008; 3 , e2637. http://dx.doi.org/10.1371/journal.pone.0002637

[44] NAKAMURA M, KYO S, ZHANG B, ZHANG X, MIZUMOTO Y et al. Prognostic impact of CD133 expression as a tumor-initiating cell marker in endometrial cancer. Hum Pathol 2010; 41, 1516-1529. http://dx.doi.org/10.1016/ j.humpath.2010.05.006

[45] KHALIL MA HJ, CIPRO S, VICHA A, ECKSCHLAGER T. (2011) Effect of histone deacetylase inhibitor on expression of CD133 in neuroblastoma cell line, in Biologicke dny Plzen; Plzen, Czech Republic.

[46] JAKSCH M, MUNERA J, BAJPAI R, TERSKIKH A, OSHIMA RG. Cell cycle-dependent variation of a CD133 epitope in human embryonic stem cell, colon cancer, and melanoma cell lines. Cancer Res 2008; 68, 7882-7886. http://dx.doi. org/10.1158/0008-5472.CAN-08-0723

[47] MARIS JM, HOGARTY MD, BAGATELL R, COHN SL. Neuroblastoma. Lancet 2007; 369, 2106-2120.

[48] COHN SL, PEARSON AD, LONDON WB, MONCLAIR T, AMBROS PF et al. The International Neuroblastoma Risk Group (INRG) classification system: an INRG Task Force report. J Clin Oncol 2009; 27, 289-297. http://dx.doi. org/10.1200/JCO.2008.16.6785
[49] MUGISHIMA H. Current status of molecular biology and treatment strategy for neuroblastoma. Int J Clin Oncol 2012; May 16. [Epub ahead of print]. http://dx.doi.org/10.1007/ $\underline{\text { s10147-012-0423-7 }}$

[50] HARA J. Development of treatment strategies for advanced neuroblastoma. Int J Clin Oncol 2012; May 16. [Epub ahead of print]. http://dx.doi.org/10.1007/s10147-012-0417-5

[51] CICCARONE V, SPENGLER BA, MEYERS MB, BIEDLER JL, ROSS RA. Phenotypic diversification in human neuroblastoma cells: expression of distinct neural crest lineages. Cancer Res 1989; 49, 219-225.

[52] WALTON JD, KATTAN DR, THOMAS SK, SPENGLER BA, GUO HF et al. Characteristics of stem cells from human neuroblastoma cell lines and in tumors. Neoplasia 2004; 6, 838-845. http://dx.doi.org/10.1593/neo.04310

[53] TONG QS, ZHENG LD, TANG ST, RUAN QL, LIU Y et al. Expression and clinical significance of stem cell marker CD133 in human neuroblastoma. World J Pediatr 2008; 4, 58-62. http://dx.doi.org/10.1007/s12519-008-0012-z

[54] TAKENOBU H, SHIMOZATO O, NAKAMURA T, OCHIAI $\mathrm{H}$, YAMAGUCHI Y et al. CD133 suppresses neuroblastoma cell differentiation via signal pathway modification. Oncogene 2011; 30, 97-105. http://dx.doi.org/10.1038/onc.2010.383

[55] KAMIJO T, NAKAGAWARA A. Molecular and genetic bases of neuroblastoma. Int J Clin Oncol 2012; May 16. [Epub ahead of print]. http://dx.doi.org/10.1007/s10147-012-0415-7

[56] COULON A, FLAHAUT M, MUHLETHALER-MOTTET A, MEIER R, LIBERMAN J et al. Functional sphere profiling reveals the complexity of neuroblastoma tumor-initiating cell model. Neoplasia 2011; 13, 991-1004.

[57] HANSFORD LM, MCKEE AE, ZHANG L, GEORGE RE, GERSTLE JT et al. Neuroblastoma cells isolated from bone marrow metastases contain a naturally enriched tumor-initiating cell. Cancer Res 2007; 67, 11234-11243. http://dx.doi. org/10.1158/0008-5472.CAN-07-0718

[58] COURNOYER S, NYALENDO C, ADDIOUI A, BELOUNIS A, BEAUNOYER $M$ et al. Genotype analysis of tumorinitiating cells expressing CD133 in neuroblastoma. Genes Chromosomes Cancer 2012; 51, 792-804. http://dx.doi. org/10.1002/gcc. 21964

[59] CASTELO-BRANCO P, ZHANG C, LIPMAN T, FUJITANI M, HANSFORD L et al. Neural tumor-initiating cells have distinct telomere maintenance and can be safely targeted for telomerase inhibition. Clin Cancer Res 2011; 17, 111-121. http://dx.doi.org/10.1158/1078-0432.CCR-10-2075

[60] SMITH KM, DATTI A, FUJITANI M, GRINSHTEIN $\mathrm{N}$, ZHANG L et al. Selective targeting of neuroblastoma tumour-initiating cells by compounds identified in stem cell-based small molecule screens. EMBO Mol Med 2010; 2, 371-384.

[61] HIRSCHMANN-JAX C, FOSTER AE, WULF GG, GOODELL MA, BRENNER MK. A distinct „side population“ of cells in human tumor cells: implications for tumor biology and therapy. Cell Cycle 2005; 4, 203-205. http://dx.doi. org/10.4161/cc.4.2.1406

[62] VANGIPURAM SD, WANG ZJ, LYMAN WD. Resistance of stem-like cells from neuroblastoma cell lines to commonly 
used chemotherapeutic agents. Pediatr Blood Cancer 2010; 54, 361-368. http://dx.doi.org/10.1002/pbc.22351

[63] OHMICHI M, HAYAKAWA J, TASAKA K, KURACHI H, MURATA Y. Mechanisms of platinum drug resistance. Trends Pharmacol Sci 2005; 26, 113-116. http://dx.doi.org/10.1016/ j.tips.2005.01.002

[64] OWENS DM, KEYSE SM. Differential regulation of MAP kinase signalling by dual-specificity protein phosphatases. Oncogene 2007; 26, 3203-3213. http://dx.doi.org/10.1038/ si.onc. 1210412

[65] NEWTON TC, WOLCOTT K, ROBERTS SS. Comparison of the side populations in pretreatment and postrelapse neuroblastoma cell lines. Transl Oncol 2010; 3, 246-251.

[66] HREBACKOVA J, HRABETA J, ECKSCHLAGER T. Valproic acid in the complex therapy of malignant tumors. Curr Drug Targets 2010; 11, 361-379. http://dx.doi.org/10.2174/ 138945010790711923
[67] BUG G, GUL H, SCHWARZ K, PFEIFER H, KAMPFMANN $\mathrm{M}$ et al. Valproic acid stimulates proliferation and self-renewal of hematopoietic stem cells. Cancer Res 2005; 65, 2537-2541. http://dx.doi.org/10.1158/0008-5472.CAN$\underline{04-3011}$

[68] DEBEB BG, XU W, MOK H, LI L, ROBERTSON F et al. Differential radiosensitizing effect of valproic acid in differentiation versus self-renewal promoting culture conditions. Int J Radiat Oncol Biol Phys 2010; 76, 889-895. http://dx.doi. org/10.1016/j.ijrobp.2009.09.052

[69] BABA T, CONVERY PA, MATSUMURA N, WHITAKER $\mathrm{RS}, \mathrm{KONDOH} \mathrm{E}$ et al. Epigenetic regulation of CD133 and tumorigenicity of CD133+ ovarian cancer cells. Oncogene 2009; 28, 209-218. http://dx.doi.org/10.1038/onc.2008.374

[70] CIPRO S, HREBACKOVA J, HRABETA J, POLJAKOVA J, ECKSCHLAGER T. Valproic acid overcomes hypoxia-induced resistance to apoptosis. Oncol Rep 2011; 27, 1219-1226. 